\title{
Video Article \\ Antibody Binding Specificity for Kappa (Vk) Light Chain-containing Human (IgM) Antibodies: Polysialic Acid (PSA) Attached to NCAM as a Case Study
}

\author{
Jens O. Watzlawik ${ }^{1,2,3}$, Robert J. Kahoud ${ }^{1,3,5}$, Bharath Wootla ${ }^{1,2,3}$, Meghan M. Painter ${ }^{1,2,3}$, Arthur E. Warrington ${ }^{1,2,3}$, William A. Carey ${ }^{3,4}$, \\ Moses Rodriguez ${ }^{1,2,3}$ \\ ${ }^{1}$ Department of Neurology, Mayo Clinic \\ ${ }^{2}$ Mayo Clinic Center for Multiple Sclerosis and Autoimmune Neurology, Mayo Clinic \\ ${ }^{3}$ Center for Regenerative Medicine, Neuroregeneration, Mayo Clinic \\ ${ }^{4}$ Division of Neonatal Medicine, Mayo Clinic \\ ${ }^{5}$ Department of Pediatric and Adolescent Medicine, Mayo Clinic
}

Correspondence to: Jens O. Watzlawik at watzlawik.jens@mayo.edu, Moses Rodriguez at rodriguez.moses@mayo.edu

URL: https://www.jove.com/video/54139

DOI: doi:10.3791/54139

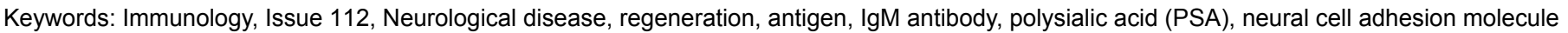
(NCAM), multiple sclerosis (MS), immunotherapy

Date Published: 6/29/2016

Citation: Watzlawik, J.O., Kahoud, R.J., Wootla, B., Painter, M.M., Warrington, A.E., Carey, W.A., Rodriguez, M. Antibody Binding Specificity for

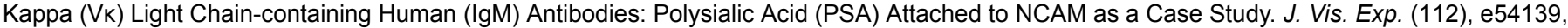
doi:10.3791/54139 (2016).

\section{Abstract}

Antibodies of the IgM isotype are often neglected as potential therapeutics in human trials, animal models of human diseases as well as detecting agents in standard laboratory techniques. In contrast, several human IgMs demonstrated proof of efficacy in cancer models and models of CNS disorders including multiple sclerosis (MS) and amyotrophic lateral sclerosis (ALS). Reasons for their lack of consideration include difficulties to express, purify and stabilize IgM antibodies, challenge to identify (non-protein) antigens, low affinity binding and fundamental knowledge gaps in carbohydrate and lipid research.

This manuscript uses HIgM12 as an example to provide a detailed protocol to detect antigens by Western blotting, immunoprecipitations and immunocytochemistry. HlgM12 targets polysialic acid (PSA) attached to the neural cell adhesion molecule (NCAM). Early postnatal mouse brain tissue from wild type (WT) and NCAM knockout (KO) mice lacking the three major central nervous system (CNS) splice variants NCAM180, 140 and 120 was used to evaluate the importance of NCAM for binding to HIgM12. Further enzymatic digestion of CNS tissue and cultured CNS cells using endoneuraminidases led us to identify PSA as the specific binding epitope for HIgM12.

\section{Video Link}

The video component of this article can be found at https://www.jove.com/video/54139/

\section{Introduction}

Antibodies of the IgM isotype demonstrate great therapeutic potential for the treatment of various diseases including cancer and CNS disorders

1-7. The Vollmers' group identified numerous antibodies in cancer patients for potential use as tumor-specific biomarkers or active therapeutics that are able to kill malignant cells by inducing apoptotic pathways ${ }^{4,8,9}$. Interestingly, all identified antibodies with therapeutic potential are of the IgM isotype and belong to the group of "natural autoantibodies" (NAbs)

Similarly, the Rodriguez's group identified mouse and human antibodies that stimulate remyelination in chronically demyelinated spinal cord lesions in models of multiple sclerosis (MS). Identical to antibodies with anti-cancer effects, all remyelination-promoting antibodies are NAbs and of the IgM isotype $1,6,7,10$. The precise antigens for most identified IgMs are still undetermined including the human remyelination-promoting antibody rHlgM22, currently in Phase I clinical trials for MS patients ${ }^{11}$. Despite repeated efforts by experts in the field of lipid and carbohydrate research both in the academic setting and in partnership with industry ${ }^{11}$, attempts to identify rHIgM22's antigen have not been successful. The failure of standard techniques used to identify antigens of $\lg G$ antibodies to work with IgM antibodies identifies a critical need to refine methods specific for these antibodies that most likely target carbohydrate or lipid antigens.

The focus of this manuscript is the human regenerative antibody HIgM12 and the experimental procedures used to identify its antigen. Antibody HIgM12 was identified from patients with Waldenstrom's macroglobulinemia, stimulates neurite outgrowth in vitro ${ }^{12-14}$ and targets polysialic acid (PSA) attached to the neural cell adhesion molecule (PSA-NCAM) ${ }^{15,16}$. HIgM12 extends life-span in a mouse model of ALS ${ }^{17}$ and improves functional outcome in Theiler's murine encephalomyelitis virus (TMEV)-infected mice. Specifically, HIgM12 stimulates spontaneous horizontal and vertical motor activity in chronically demyelinated mice and increases numbers of small and medium diameter spinal cord axons eight weeks after a single, low dose of intraperitoneal injected antibody ${ }^{18}$. 
The neural cell adhesion molecule (NCAM) is a glycoprotein of the immunoglobulin (Ig) superfamily expressed on the cell surface of neurons, glia, skeletal muscle, and natural killer cells ${ }^{19-25}$. The three major NCAM isoforms termed NCAM180, NCAM140, and NCAM120, are alternative splice variants of a primary transcript that vary only in their cytoplasmic domain. Within the CNS, NCAM is the major polysialylated molecule (> $95 \%$ ) with long, negatively charged sialic acid homopolymers. Polysialic acid with $n>10$ is termed PSA but shorter oligomeric structures exist that are also biologically relevant. Other polysialylated proteins expressed in the CNS are SynCAM1 ${ }^{26}$, Neuropilin-2 (NRP-2) ${ }^{27,28}$ and a sodium channel subunit ${ }^{25}$ (for review see ${ }^{29}$ ).

The methods described here permit antigen identification for human and mouse immunoglobulins containing specific kappa (VK) light chains (VKI, VKIII or VKIV light chains for human antibodies and VKI light chains for mouse antibodies) irrespective of the antibody's isotype (e.g., IgG, $\lg M, \lg A, \lg D$ or $\lg E)$. This limitation is based on use of protein $L$ agarose for immunoprecipitations with antibodies of the IgM isotype. Alternative strategies may include mannose-binding lectins and secondary IgG anti-lgM antibodies covalently linked to agarose beads, which may broaden the applicability of this method to more IgM antibodies including those with lambda $(\lambda)$ light chains (see discussion). Ratios of serum IgM VK light chains compared to $\operatorname{lgM} \lambda$ light chains derived from healthy individuals are 1.5:1 ${ }^{30}$.

Based on the chromatographic methodology used here to separate, enrich, and immunologically detect certain molecules ${ }^{31}$, all antigens are required to include at least one small protein domain. The antibody's specific binding epitope can be within or outside the protein domain (e.g., in glycoproteins, lipoproteins). Initial biochemical steps used to identify the specific antigen for HIgM12, respective to narrow down the list of potential candidates, are the most crucial steps in this method. Cell type specific preparations and cell morphology-based characterizations are described for glial cells but this methodology can be extrapolated to accommodate other cell types within or outside the CNS.

There is an urgent need to develop new or modified techniques applicable for the increasing number of IgM antibodies with therapeutic potential for different human disorders particularly in those cases (the majority of IgM antigens) where the antibody targets are carbohydrate or lipid structures.

\section{Protocol}

Animal protocols and procedures were conducted in accordance with the National Institutes of Health guidelines and approved by the Mayo Clinic's institutional animal care and use committees (Mayo IACUC protocol number \#A51912).

\section{General CNS Tissue Preparation}

1. Generate NCAM deficient (KO) mice on C57/BI6 background (kindly provided by Dr. Lynn Landmesser, Case Western Reserve University, Cleveland, Ohio), heterozygous NCAM mice and wild type (WT) littermates (C57/BI6) by crossing heterozygotes. Genotyping of NCAM KO mice was described previously ${ }^{32-34}$ and will not be explained in further detail.

Note: Steps 1.2 - 1.6 are Optional.

2. Prior to surgery, administer a pentobarbital solution (Stock: $25 \mathrm{mg} / \mathrm{ml} ; 50 / 100 \mu \mathrm{l}$ of pentobarbital for early postnatal respective adult stages) via intraperitoneal injection (27 gauge needle and $1 \mathrm{ml}$ syringe).

3. Wait for 2 min or until the animal has reached a surgical plane of anesthesia. Administer additional anesthetic as necessary during the course of each operation to maintain a surgical plane of anesthesia. Use toe pinch-response method to determine depth of anesthesia. Animals must be unresponsive before continuing.

4. Make a $0.5-1 \mathrm{~cm}$ lateral incision through the integument and abdominal wall just beneath the rib cage. Carefully separate the liver from the diaphragm. Make a small incision in the diaphragm using a curved, blunt scissors. Continue the diaphragm incision along the entire length of the rib cage to expose the pleural cavity.

5. Place curved, blunt scissors along one side of the rib cage, carefully displacing the lungs, and make a cut through the rib cage up to the collarbone. Make a similar cut on the contralateral side. Lifting the sternum away, carefully trim any tissue connecting it to the heart.

6. Make an incision to the animal's right atrium using iris scissors to create as large an outlet as possible. Slowly inject $10 \mathrm{ml}$ of phosphate buffered saline (PBS) into the animal's left ventricle (light red; flow rate: $1 \mathrm{ml} / \mathrm{min}$ ) by using a $10 \mathrm{ml}$ syringe equipped with 27 -gauge needle. Do not increase the pressure/PBS flow during the perfusion to avoid tissue destruction.

7. Decapitate neonatal mice by using surgical scissors.

8. Remove the brain by grabbing the eye sockets with a forceps and by inserting a small scissors into the spinal column. Cut the skull toward the front at ear level. Peel back the skull and gently place the brain into a $60 \mathrm{~mm}$ Petri dish filled with $10 \mathrm{ml}$ of ice-cold dissecting medium on ice (Table 1). Place each brain in a $1.5 \mathrm{ml}$ microcentrifuge tube and immediately store on dry ice $\left(-79^{\circ} \mathrm{C}\right)$.

9. Incise the cerebellum and brain stem from frozen brains using a clean razor blade on ice. Work quickly to avoid thawing the tissue.

10. Weigh the frozen cerebrum, put in a $15 \mathrm{ml}$ tube on ice and add ice-cold lysis buffer (see Table 1) to a final concentration of $150 \mu \mathrm{g}$ brain tissue per $\mu \mathrm{l}$ lysis buffer. Repeat for remaining cerebra. Keep brains on ice at all times for steps $1.9-1.11$.

11. Homogenize brains in lysis buffer by trituration through a $1 \mathrm{ml}$ pipette tip (10 times) followed by trituration through a $5 \mathrm{ml}$ syringe equipped with 27-gauge needle (10 times). Incubate brain lysates for additional $30 \mathrm{~min}$ on ice to allow complete tissue lysis.

12. Remove detergent-insoluble material and brain lipids through serial centrifugation (four rounds at $19,000 \times \mathrm{g}$ for $10 \mathrm{~min}$ at $4{ }^{\circ} \mathrm{C}$ ). Discard (white) myelin and cell debris containing pellet but retain the supernatant after every centrifugation step. Aliquot brain lysates and store at -80 ${ }^{\circ} \mathrm{C}$.

\section{Immunoprecipitations Using Human IgMs (HIgM12 and Isotype Control IgM) as a "Pull- down" Agent from Cerebral Lysates of WT and NCAM KO Mice}

1. Protein L Agarose Bead Preparation ${ }^{9,35,36}$

1. Prepare $200 \mathrm{ml}$ of IP buffer including BSA (see Table 1). Prepare another $200 \mathrm{ml}$ of the same IP buffer without BSA. 
2. Per immunoprecipitation reaction transfer $100 \mu \mathrm{l}$ of Protein L Agarose slurry using a $200 \mu \mathrm{l}$ pipette into a $1.5 \mathrm{ml}$ microcentrifuge tube. Do not vortex protein L agarose beads! Add $1 \mathrm{ml}$ of IP buffer (see Table 1) to each tube. Mix Protein L agarose and IP buffer manually through inversion (five times).

3. Wash protein $L$ agarose beads four times by centrifugation in a benchtop centrifuge $\left(1,000 \times \mathrm{g}, 2 \mathrm{~min}, 25^{\circ} \mathrm{C}\right)$. Take off supernatant using a $200 \mu \mathrm{l}$ pipette without disturbing the agarose pellet. Repeat washing steps 2.1.2 to 2.1 .3 three additional times.

4. Equilibrate protein $\mathrm{L}$ agarose in $1 \mathrm{ml}$ of freshly added IP buffer on a roller overnight at $4{ }^{\circ} \mathrm{C}$.

\section{Antibody-Antigen-Agarose L Complex Formation and Antigen Detection in Western Blots}

1. Incubate $30 \mathrm{mg}$ of lysed brain tissue $(\sim 200 \mu \mathrm{l}$ lysate) in $1 \mathrm{ml}$ of ice-cold IP buffer with $20 \mu \mathrm{g}$ of IgM antibody (HIgM12) in a $1.5 \mathrm{ml}$ microcentrifuge tube overnight on a roller at $4^{\circ} \mathrm{C}$.

2. Spin down protein $L$ agarose beads (from step 2.1.4) in a benchtop centrifuge for 2 min at $1,000 \times g, 4^{\circ} \mathrm{C}$. Discard the supernatant using a $200 \mu \mathrm{l}$ pipette without disturbing the agarose pellet. Add the chilled antibody-brain lysate solution (from step 2.2.1) to the protein $\mathrm{L}$ agarose using a $1 \mathrm{ml}$ pipette.

3. Incubate the antibody-antigen-protein $\mathrm{L}$ agarose suspension for $2 \mathrm{hr}$ on a roller at $4^{\circ} \mathrm{C}$. Wash the antibody-antigen complex attached to agarose $\mathrm{L}$ through centrifugation at $1,000 \times \mathrm{g}$ for $2 \mathrm{~min}, 4^{\circ} \mathrm{C}$. Carefully discard the supernatant without disturbing the pellet and add 1 $\mathrm{ml}$ of ice-cold IP buffer containing $0.2 \%$ BSA.

4. Repeat the washing step one more time using ice-cold IP buffer containing $0.2 \%$ BSA and two additional times using ice-cold IP buffer without BSA.

5. Spin down antibody-antigen complex attached to agarose $L$ at $1,000 \times g$ for $2 \mathrm{~min}, 4^{\circ} \mathrm{C}$. Discard supernatant completely first using a $200 \mu \mathrm{l}$ pipette until $\sim 50 \mu \mathrm{l}$ of solution are left on top of the protein L agarose pellet followed by a $10 \mu \mathrm{l}$ pipette. Keep samples on ice.

6. Add $40 \mu$ of IP elution buffer (see Table 1) per $1.5 \mathrm{ml}$ microcentrifuge tubes, finger flick tubes 6 times and heat for $5 \mathrm{~min}$ at $95^{\circ} \mathrm{C}$. Put samples on ice for $2 \mathrm{~min}$ and spin down for $30 \mathrm{sec}$ at $13,000 \mathrm{xg}, 4^{\circ} \mathrm{C}$.

7. Transfer supernatant using a $10 \mu \mathrm{l}$ pipette $(\sim 35 \mu \mathrm{l}$ total) into a fresh $1.5 \mathrm{ml}$ microcentrifuge tube without disturbing the pellet. Confirm absence of Protein $L$ agarose beads by rinsing down a small amount of eluted sample at the inner tube wall.

Note: "Granular" protein $L$ agarose beads are clearly visible if present.

8. If protein $L$ agarose beads are present, spin down sample for another $30 \mathrm{sec}$ at $13,000 \times \mathrm{g}$ and transfer supernatant to clean tube. Repeat step until no agarose beads are detectable.

9. Load $10-20 \mu$ of eluted samples per well on SDS-polyacrylamide gel in a Tris/Glycine/SDS buffer system (see Table 1). Note: Use $7.5 \%$ or $4-20 \%$ gradient gels with $50 \mu$ l loading volume per well for the detection of PSA-NCAM or NCAM isoforms (gel dimensions (W x L x thickness: $8.6 \times 6.7 \times 0.1 \mathrm{~cm})$.

10. Run gels for $\sim 1 \mathrm{hr}$ at $100 \mathrm{~V}\left(1.74 \mathrm{~V} / \mathrm{cm}^{2}\right)$ on benchtop. Additional cooling is not required for this $\operatorname{step}^{37,38}$

11. Transfer proteins to PVDF (polyvinylidene fluoride) membrane (pore size $0.45 \mu \mathrm{m}$ ) for $2.5 \mathrm{hr}$ in the cold room at $100 \mathrm{~V}\left(1.74 \mathrm{~V} / \mathrm{cm}^{2}\right.$ ) using cold transfer buffer $\left(5-10^{\circ} \mathrm{C}\right)$ (see Table 1).

12. Block membranes with $10 \%$ (w/v) dry milk powder in PBS-T for $1 \mathrm{hr}$ at $25^{\circ} \mathrm{C}$ on a benchtop orbital shaker, wash membranes twice for 10 min with PBS-T and probe overnight with primary antibody in 5\% BSA in PBS-T on an orbital shaker in the cold room.

13. The next morning wash membranes one time briefly with excess PBS-T at $25^{\circ} \mathrm{C}$ (include lid and container) followed by 3 washes with PBS-T for 10 min each on an orbital shaker (80 rpm) (all washing steps are performed at $25^{\circ} \mathrm{C}$ ).

14. Add secondary antibody (horseradish peroxidase (HRP)-conjugated anti-human anti-IgM antibody (for HIgM12) (dilution 1:30,000) in $5 \%$ dry milk powder in PBS-T for $1 \mathrm{hr}$ at $25^{\circ} \mathrm{C}$ on an orbital shaker (70 rpm).

15. Wash membranes extensively one time briefly with excess PBS-T at $25^{\circ} \mathrm{C}$ (include lid and container) followed by 3 washes with PBS-T for $10 \mathrm{~min}$ each on an orbital shaker ( $80 \mathrm{rpm}$ ) (all washing steps are performed at $25^{\circ} \mathrm{C}$ ).

16. Mix $1 \mathrm{ml}$ of chilled enhanced chemiluminescence HRP substrate component A (enhanced luminol reagent) with $1 \mathrm{ml}$ of component $B$ (Oxidizing reagent) (per mini blot) at $25^{\circ} \mathrm{C}$.

17. Use plastic forceps to transfer the membranes on a paper towel to remove excess liquid (hold them at the very edges). Dry containers with paper towels and put membranes back into the containers (one for each membrane). Immediately add $2 \mathrm{ml}$ of the pre-mixed enhanced chemiluminescence HRP substrate (compound A+B) (step 2.2.16.) to each membrane and incubate for 2 min at $25^{\circ} \mathrm{C}$ on an orbital shaker $(90 \mathrm{rpm})$. Make sure membranes are uniformly moistened by the chemiluminescence reagent.

18. Transfer membranes into a transparent plastic sleeve and remove excess liquid and air bubbles with paper towels. Put membranes in plastic sleeve in a film cassette and eventually tape the plastic sleeve into the cassette. Close the cassette.

19. Take the cassette, film, timer and scissors into the darkroom. Cut off upper right corner from each film for orientation purposes, expose (different) films for different periods of time (10 sec, $1 \mathrm{~min}, 10 \mathrm{~min}$ ) and develop films in a film developer.

\section{Endoneuraminidase-NF Digestion of PSA Attached to NCAM ${ }^{39}$}

1. Digest lysed brain tissue from postnatal day (P) 7 WT mice and P7 NCAM KO mice (prepared from step 1.12) for $2 \mathrm{hr}$ on ice using endoneuraminidase-NF (ENDO-NF) as illustrated in Table ${ }^{39}$.

2. Add $5 \mu$ l of $4 x$ Laemmli sample buffer to each tube $(1-6)$ from step 3.1 (Table 2).

3. Load samples on a 4 - 20\% gradient SDS-polyacrylamide gel and repeat steps 2.2.10 to 2.2.19. Probe membranes with $\mathrm{HlgM} 12(1 \mu \mathrm{gg} / \mathrm{ml})$, commercially available anti-PSA mAb (clone $2-2 \mathrm{~B})(1 \mu \mathrm{g} / \mathrm{ml})$ and $\beta$-actin antibody (loading control) $(1 \mu \mathrm{g} / \mathrm{ml})$ in $5 \%$ BSA in PBS-T.

\section{Preparation of Rat and Mouse CNS Cultures}

\section{Preparation of Glass Coverslips}

1. Acid-wash $25 \mathrm{~mm}$ glass coverslips in $1 \mathrm{M} \mathrm{HCl}$ at $50-60^{\circ} \mathrm{C}$ for $4-16 \mathrm{hr}$ in a fume hood using a glass container. Agitate coverslips occasionally through gentle swirling.

2. Wash glass coverslips extensively in distilled water (3x). Make sure to wash out the acid between stacked coverslips.

3. Rinse coverslips in $100 \%$ ethanol and dry them on Parafilm in a cell culture hood. One day before usage, heat the glass coverslips for $24 \mathrm{hr}$ in a glass container with lid at $100^{\circ} \mathrm{C}$ in an oven. 
4. Put glass coverslips in 6-well dish and coat with $3 \mathrm{ml}$ of $40 \mu \mathrm{g} / \mathrm{ml}$ poly-D-lysine in sterile water for $1 \mathrm{hr}$ at $37^{\circ} \mathrm{C}$.

5. Wash twice with sterile water, dry completely under cell culture hood and apply UV light for $20 \mathrm{~min}$.

\section{Preparation of Tissue Culture Plastic for CNS Cells}

1. Coat $60 \mathrm{~mm}$ cell culture dishes or $75 \mathrm{~cm}^{2}$ tissue culture flasks with $3 \mathrm{ml}$ or $10 \mathrm{ml}$, respectively, of $40 \mu \mathrm{g} / \mathrm{ml}$ poly-D-lysine in sterile water for $1 \mathrm{hr}$ at $37^{\circ} \mathrm{C}$.

2. Wash twice with water, dry completely under cell culture hood and apply UV light for $20 \mathrm{~min}$.

3. Rat mixed Glia Isolation 40

1. Anesthetize neonatal rats in IACUC approved rodent euthanasia chamber with $\mathrm{CO}_{2}$ gas supply (fully automatized). Use toe pinchresponse method to determine the animal's unresponsiveness. Decapitate neonatal Sprague Dawley rat (P0P1) (6 - 10 pups at a time).

2. Remove the brain by grabbing the eye sockets with a forceps and by inserting a small scissors into the spinal column. Cut the skull toward the front at ear level. Peel back the skull and gently place the brain into a $60 \mathrm{~mm}$ Petri dish filled with $10 \mathrm{ml}$ of ice-cold dissecting medium on ice (see Table 1).

3. Repeat for remaining rat pups (6 - 10 pups). Keep tissue on ice for steps 4.3.2 - 4.3.7.

4. Divide the cerebrum along the midline into two cerebral hemispheres and subsequently cut off olfactory bulbs, basal ganglia below the cerebral cortex and the hippocampus with Dumont forceps. Place the isolated cerebral cortex in a clean Petri dish containing dissecting medium on ice.

5. Take one cortex. Remove the meninges with forceps with fine tips under a dissection microscope.

6. Repeat with the remaining cortices. Place all meninges-free cortices into one clean Petri dish on ice.

7. Combine cortical hemispheres from all pups in a $60 \mathrm{~mm}$ Petri dish and use a sterile razor blade to dice the brain tissue into $1 \mathrm{~mm}$ minced pieces.

8. Transfer the minced brain tissue using a $10 \mathrm{ml}$ pipette into a sterile, uncoated $500 \mathrm{ml}$ glass flask and add $10 \mathrm{ml}$ of ice-cold dissecting medium per rat brain. Gently swirl the flask while adding $1 \mathrm{ml}$ of trypsin solution in HBSS (Hank's Balanced Salt Solution) $(5 \mathrm{mg} / \mathrm{ml}$ trypsin) to $9 \mathrm{ml}$ of HBSS per rat brain. Add $2 \%$ of the total volume in DNase I solution $(1 \mathrm{mg} / \mathrm{ml})$ and $2 \%$ of the total volume in $\mathrm{MgSO}_{4}$ solution $\left(3.82 \% \mathrm{MgSO}_{4}\right.$ in $\left.\mathrm{HBSS}(\mathrm{w} / \mathrm{v})\right)$ to the brain tissue suspension and swirl gently.

9. Trypsinize tissue under gentle shaking on a rotational shaker for $30 \mathrm{~min}$ at $37^{\circ} \mathrm{C}$. Make sure tissue pieces are floating during this step and do not sediment to the bottom. Increase rotating speed if necessary.

10. Add fetal bovine serum (FBS) to a final concentration of $10 \%(\mathrm{v} / \mathrm{v})$ and mix by swirling the flask 10 times for 10 sec. Cool down tissue suspension in ice water for $15 \mathrm{~min}$. Swirl flask gently five times every second min.

11. Gently transfer the tissue suspension into sterile $50 \mathrm{ml}$ tubes using $25 \mathrm{ml}$ or $50 \mathrm{ml}$ pipettes and centrifuge for $5 \mathrm{~min}$ at $200 \times \mathrm{g}, 4^{\circ} \mathrm{C}$.

12. Discard supernatant and gently resuspend digested CNS tissue in $15 \mathrm{ml}$ of ice-cold dissecting medium supplemented with $5 \mathrm{ml}$ of fetal bovine serum, $0.4 \mathrm{ml} \mathrm{MgSO}_{4}$ solution (3.82\% $\mathrm{MgSO}_{4}$ in HBSS) and $1.6 \mathrm{ml}$ of DNase I $(1 \mathrm{mg} / \mathrm{ml})$.

13. Split tissue suspension equally into two sterile $15 \mathrm{ml}$ tubes $(\sim 10 \mathrm{ml}$ each) and slowly triturate using a $10 \mathrm{ml}$ pipette (10 times) until the suspension becomes turbid/milky. Keep suspended cells on ice while processing the next tube. Wait for 3 min until remaining digested CNS tissues sediment to the bottom of the tube. Transfer supernatant to clean $50 \mathrm{ml}$ tube without disturbing the pellet fraction.

14. Optionally, pass turbid supernatants through 40 -micron cell strainer and combine the resulting single cell suspension into sterile $50 \mathrm{ml}$ tubes on ice.

15. Spin cell slurry for $5 \mathrm{~min}$ at $200 \times \mathrm{g}, 4^{\circ} \mathrm{C}$

16. Gently remove the supernatant using a $10 \mathrm{ml}$ pipette until $\sim 2 \mathrm{ml}$ of dissecting medium are left on top of the cell pellet.

17. Finger flick cell pellets in $50 \mathrm{ml}$ tubes ( 10 times). Slowly add $5 \mathrm{ml}$ of warm growth medium (see Table 1 ) to the cell suspension while gently hand swirling the tube.

18. Optionally, repeat DNase step 4.3.12 for an additional $10 \mathrm{~min}$ on ice with fresh DNase I solution and $\mathrm{MgSO}_{4}$-solution in case of visible tissue clusters or DNA clumps. Swirl tube manually 5 times every second min.

19. Plate 50,000 cells per $25 \mathrm{~mm}$ glass coverslip in a puddle of $400 \mu \mathrm{l}$ growth medium in a 6 -well dish and let cells attach for $30 \mathrm{~min}$ in a cell culture incubator $\left(5 \% \mathrm{CO}_{2}, 37^{\circ} \mathrm{C}\right)$.

20. For confluent (within $24-48 \mathrm{hr}$ after plating) $60 \mathrm{~mm}$ cell culture dishes and $75 \mathrm{~cm}^{2}$ tissue culture flasks, plate 500,000 cells $(60 \mathrm{~mm}$ dish) or 2 million cells $\left(75 \mathrm{~cm}^{2}\right.$ flasks).

21. Gently add $2 \mathrm{ml}$ (per well, $25 \mathrm{~mm}$ glass coverslips in 6-well dish), $3 \mathrm{ml}\left(60 \mathrm{~mm}\right.$ dishes) or $10 \mathrm{ml}\left(75 \mathrm{~cm}^{2}\right.$ flasks) of warm growth medium to each well. Incubate cells overnight and change medium completely the next morning. Then change medium every other day (day 3 , day 5 , day 7 , etc.).

Note: Rat mixed glia cultures are ready to use for immunocytochemistry or biochemistry 24 - $48 \mathrm{hr}$ after plating

\section{Mouse Mixed Glial Cultures}

1. Identical to the dissection of neonatal rat brains described in sections 4.3.1 to 4.3.6, decapitate PO neonatal WT and NCAM KO mice with C57/BI6 background, remove brains and put them in ice-cold dissecting medium (see Table 1). Keep tissue on ice at all times.

2. Divide the cerebrum along the midline into two cerebral hemispheres and subsequently cut off olfactory bulbs, basal ganglia below the cerebral cortex and the hippocampus with Dumont forceps. Place the isolated cerebral cortex in a clean Petri dish containing HBSS on ice.

3. Take one cortex. Remove the meninges with forceps with fine tips under a dissection microscope. Repeat with the remaining cortices. Place all meninges-free cortices into one clean Petri dish on ice.

4. Transfer cortical hemispheres with $1 \mathrm{ml}$ pipette from each mouse into separate, sterile $15 \mathrm{ml}$ tubes. Add $1.2 \mathrm{ml}$ ice-cold dissecting medium to each brain and mechanically disrupt the brain tissue by pipetting it 2 times up and down using a $1 \mathrm{ml}$ pipette tip.

5. Add $150 \mu \mathrm{l}$ papain solution ( $10 \mathrm{mg} / \mathrm{ml}$ in PBS), $100 \mu \mathrm{l} \mathrm{DNase} \mathrm{I} \mathrm{solution} \mathrm{(} 1 \mathrm{mg} / \mathrm{ml}$ in HBSS) and $50 \mu \mathrm{lggSO}$ (3.82\% in HBSS) to each brain and mix by finger flicking.

6. Incubate the brain suspension for $30 \mathrm{~min}$ at $37^{\circ} \mathrm{C}$ in a water bath and mix brain suspensions every second minute by finger flicking Add $1 \mathrm{ml}$ of FBS per tube, mix and cool down the tissue suspension for $10 \mathrm{~min}$ on ice.

7. Spin down the brain tissue for $4 \mathrm{~min}$ at $200 \mathrm{xg}, 4^{\circ} \mathrm{C}$ and resuspend the tissue pellet in $1 \mathrm{ml}$ of ice-cold dissecting buffer supplemented with $70 \mu \mathrm{l}$ of DNase I solution ( $1 \mathrm{mg} / \mathrm{ml}$ in HBSS) and $30 \mu \mathrm{l} \mathrm{MgSO}_{4}$ solution (3.82\% in HBSS). 
8. Triturate the brain tissue using a FBS-coated $1 \mathrm{ml}$ pipette tip $(\sim 5$ times $)$ until the supernatant becomes turbid. Pass the supernatant through a 40 -micron cell strainer and transfer into a clean tube on ice.

9. Pellet mixed glial cells through centrifugation for $5 \mathrm{~min}$ at $200 \mathrm{xg}, 4^{\circ} \mathrm{C}$. Aspirate supernatant until $\sim 100 \mu \mathrm{l}$ of medium are left on top of the cell pellet. Resuspend cell pellet by finger flicking ( $\sim$ times) and add $1 \mathrm{ml}$ of warm mouse growth medium (see Table 1).

10. Optionally, dissolve visible cell clusters and lysed cells/precipitated DNA by gently pipetting the cell suspension up and down (five times).

11. Plate mouse mixed glial cells on PDL-coated glass coverslips or $60 \mathrm{~mm}$ dishes as described in steps 4.3.19-4.3.21. Wash cells the next morning with warm mouse growth medium and subsequently every other day. Mouse mixed glia is ready to use for immunocytochemistry 48 - $72 \mathrm{hr}$ after plating.

\section{Rat Microglia Isolation}

1. Culture rat mixed glia in $75 \mathrm{~cm}^{2}$ tissue culture flasks in growth medium (see Table 1) for 10 days. Shake off microglial cell clusters from mixed glial cultures on a rotational shaker inside a cell culture incubator $\left(5 \% \mathrm{CO}_{2}, 37^{\circ} \mathrm{C}\right)$ at $140 \mathrm{rpm}$ for $1 \mathrm{hr}$.

2. Take off the microglia-containing supernatant from mixed glia cultures, pass it through a 40-micron cell strainer and keep the cell suspension in sterile $50 \mathrm{ml}$ tubes.

Note: Microglial cultures are typically $>95 \%$ pure after this step with few contaminating OPCs and very few astrocytes.

3. Optionally, replace growth medium on mixed glia cultures for future microglial shake-offs. Typically perform multiple microglial shakeoffs (once per week) from mixed glial cultures.

4. Optionally, to get purities higher $95 \%$ plate $10 \mathrm{ml}$ of the microglia-containing supernatant (step 4.5.2) per $100 \mathrm{~mm}$ Petri dishes and incubate in a cell culture incubator for $30 \mathrm{~min}$ at $37^{\circ} \mathrm{C}$. Only microglia will attach to Petri dishes, while astrocytes and OPCs remain in the supernatant

5. Gently shake Petri dishes clockwise and counterclockwise (five times each) in the cell culture hood. Aspirate cell culture medium completely and replace with $10 \mathrm{ml}$ of growth medium. Resulting microglia cultures are $>98 \%$ pure.

6. Culture microglia for up to 7 days in DMEM supplemented with $1 \%$ FBS and $1 \%$ penicillin/streptomycin.

\section{Rat OPC/oligodendrocyte Isolation}

1. To obtain highly enriched OPC cultures shake off microglial cells first from 10 day old mixed glial cultures grown in $75 \mathrm{~cm}^{2}$ flasks on a rotational shaker within a cell culture incubator $\left(5 \% \mathrm{CO}_{2}, 37^{\circ} \mathrm{C}\right)$ at $140 \mathrm{rpm}$ for $1 \mathrm{hr}$. Discard microglia only-containing supernatant or use for microglia-specific experiments (see step 5.5).

2. Replace the microglial-containing supernatant with $10 \mathrm{ml}$ growth medium and shake off mixed glial cultures for another $18 \mathrm{hr}$ on a rotational shaker at $200 \mathrm{rpm}\left(5 \% \mathrm{CO}_{2}, 37^{\circ} \mathrm{C}\right)$.

3. Collect the microglia- and OPC-containing supernatant from mixed glia cultures and pass through a 40-micron cell strainer. Collect the cell suspension in sterile $50 \mathrm{ml}$ tubes.

4. Optionally, replace growth medium on mixed glia cultures for future OPC shake-offs. Note: OPCs continue to proliferate on astrocytic feeder layers and can be shaken-off a second and third time (once per week), albeit with lower yields.

5. Plate $10 \mathrm{ml}$ of the microglia- and OPC-containing supernatant into $100 \mathrm{~mm}$ Petri dishes and incubate in cell culture incubator for $30 \mathrm{~min}$ at $37^{\circ} \mathrm{C}$. Microglia will attach to the Petri dishes, while OPCs and astrocytes remain in the supernatant.

6. Gently shake Petri dishes clockwise and counterclockwise (5 times each) in a cell culture hood. Take out only a few Petri dishes at a time from cell culture incubator (microglia will start dislodging from Petri dishes when shaken vigorously in cooler medium).

7. Collect and combine the OPC-containing supernatant in $50 \mathrm{ml}$ tubes. Optionally, add culture medium to Petri dishes for use in microglia-specific experiments.

8. Optionally, to further increase the purity of OPC cultures repeat steps 5.6.5 and 5.6.6 once with fresh Petri dishes to lower the extent of microglia in OPC preparations.

9. Spin down enriched OPC-containing supernatant in centrifuge for $5 \mathrm{~min}$ at $250 \mathrm{x} \mathrm{g}, 4^{\circ} \mathrm{C}$. Gently aspirate the supernatant without disturbing the cell pellet. Leave $3 \mathrm{ml}$ of the supernatant on top of the pellet and start resuspending OPCs by finger flicking (10 times).

10. Gently triturate OPC cell clusters by using a $10 \mathrm{ml}$ pipette $(5-10$ times).

11. Count cells and plate 50,000 OPCs per $25 \mathrm{~mm}$ glass coverslip (PDL-coated) in a puddle of $400 \mu \mathrm{l}$ growth medium in a 6-well dish and let cells attach for $30 \mathrm{~min}$ in a cell culture incubator $\left(5 \% \mathrm{CO}_{2}, 37^{\circ} \mathrm{C}\right)$. Gently add $2 \mathrm{ml}$ of warm proliferation medium (see Table 1) to each well. For PDL-coated $60 \mathrm{~mm}$ cell culture dishes, plate $1-1.5$ million OPCs in $3 \mathrm{ml}$ of proliferation medium.

12. Carefully replace FBS-containing proliferation medium with fresh proliferation medium $3 \mathrm{hr}$ after plating the OPCs (make sure OPCs attached properly and do not dislodge during medium change). Exchange medium every second day.

Note: Rat OPC cultures prepared using this protocol are typically $90 \%$ pure with microglia as the major contaminating cell type, followed by astrocytes.

\section{Immunocytochemistry Using HIgM12 in Primary Glial Cells}

1. Triple-label Immunofluorescence using HIgM12, anti-PSA mAb, and Cell type Specific Markers in Primary Glial Cells from WT and NCAM KO Mice

1. Under live cell conditions, label $60 \%$ confluent mouse mixed glia cultures from WT and NCAM KO mice grown on PDL-coated $25 \mathrm{~mm}$ glass coverslips with HIgM12 $(10 \mu \mathrm{g} / \mathrm{ml})$ and anti-PSA mAb (clone 2-2B) $(10 \mu \mathrm{g} / \mathrm{ml})$ in PBS supplemented with $10 \%$ FBS at $4{ }^{\circ} \mathrm{C}$ for 30 $\min$.

2. Wash cells three times for 20 sec each with ice-cold PBS supplemented with $10 \%$ FBS and fix with $4 \%$ paraformaldehyde in PBS, pH 7.4 for $15 \mathrm{~min}$ at $25^{\circ} \mathrm{C}$

3. Wash fixed cells two times for 1 min each with PBS supplemented with $10 \%$ FBS and permeabilize cells with $0.1 \%$ Triton-X100 in PBS, $\mathrm{pH} 7.4$ for $2 \mathrm{~min}$ at $25^{\circ} \mathrm{C}$. Wash cells twice for $1 \mathrm{~min}$ and label with glial markers GFAP (astrocytes) or IBA- 1 (microglia) $(1 \mu \mathrm{g} / \mathrm{ml})$ in PBS supplemented with $10 \%$ FBS overnight at $4{ }^{\circ} \mathrm{C}$ in the cold room.

4. Proceed with standard immunofluorescence conditions including DAPI-containing mounting medium ${ }^{31}$. 
Note: Use of fluorescently labeled $\mathrm{Fab}_{2}$ fragments as secondary antibodies for human (HIgM12) and mouse (anti-PSA mAb, clone 2 2B) IgMs is strongly recommended.

5. Take fluorescent images at 60X or 100X magnification. Use the same instrument settings for all images and process images identically.

\section{Immunofluorescence Labeling of ENDO-NF-treated WT Glia Cells using HIgM12 as a Primary Antibody}

1. Culture WT mouse mixed glia grown for 3 days in Neurobasal A supplemented with $10 \%$ FBS and B27 supplement (1:50) on PDLcoated $25 \mathrm{~mm}$ glass coverslips. Add ENDO-NF (30 $\mathrm{gg} / \mathrm{ml})$ to $1 \mathrm{ml}$ culture medium and incubate overnight in a cell culture incubator (37 ${ }^{\circ} \mathrm{C}, 5 \% \mathrm{CO}_{2}$ ).

2. Label cells live in the cold with HIgM12 and internal astrocytic marker GFAP after fixation and permeabilization as described in steps 5.1.1 to 5.1.5. Take fluorescent images at $60 \mathrm{X}$ or $100 \mathrm{X}$ magnification. Use the same instrument settings for all images and process identically.

\section{Representative Results}

This section illustrates examples of results that can be obtained by studying human IgM-specific PSA-antigens in the CNS. The use of human IgM antibodies containing specific $V_{K}$ light chains in biochemical settings and by fluorescent immunocytochemistry is shown.

HIgM12 immunoprecipitates its antigen from cerebral brain lysates and acts as a detecting agent (primary antibody) in Western blots. Neither isotype control antibody nor agarose $L$ beads immunoprecipitate a similar antigen, which demonstrates the specificity of the pull down (Figure 1). Western blots using CNS lysates from WT and NCAM KO mice demonstrate the specificity of HIgM12-binding to PSA-containing NCAM (Figure 2A). Enzymatic digestion of CNS tissue from WT mice using ENDO-NF identifies PSA attached to NCAM as the specific binding epitope for HIgM12 (Figure 2B). Using the method outlined herein, IBA-1-positive rat microglial cultures of high purity are obtained (Figure 3). Commercially available anti-PSA antibody (clone 2-2B) does not label cell surface or internal PSA pools in fixed and permeabilized IBA-1-positive microglial cells by fluorescent microscopy. Consistent with previously published literature, which reports no cell-surface expression of PSA-NCAM in microglia ${ }^{16,41}$ HIgM12 does not label cell surface antigens in purified rat microglia. Interestingly, HIgM12 labeling of fixed and permeabilized microglia results in an intracellular, perinuclear pattern that is not restricted to specific organelles (Figure 3). Results are in contrast to those obtained using an anti-PSA IgG antibody (clone 735) ${ }^{26}$, which targets PSA-SynCAM in microglia at the level of the Golgi ${ }^{41}$.

In contrast to microglia, HIgM12 and A2B5 target cell surface antigens in highly enriched rat OPC cultures under live cell conditions (Figure 4). OPC cultures contain $\sim 5 \%$ contaminating microglial cells. Figure 5 illustrates a virtually identical cell-surface staining pattern between HIgM12 and anti-PSA mAb (clone 2-2B) in GFAP-positive astrocytes (Figure 5A). Immunofluorescent labeling of ENDO-NF-digested WT astrocytes compared to buffer control-treated WT astrocytes using HIgM12 demonstrates the presence of astrocytic PSA (Figure 5B). The presence of PSA-positive astrocytes in vivo still has to be confirmed.

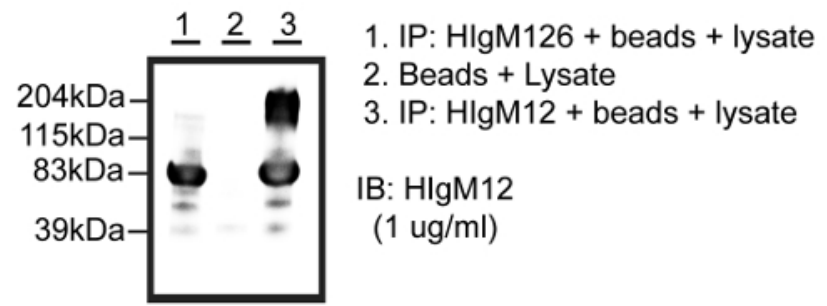

Figure 1: HIgM12 acts as a "pull-down" Agent in Immunoprecipitations. Immunoprecipitations from total brain lysate of three-month-old mice using HlgM12, human isotype control HlgM126 or agarose L beads only as "pull down" agents. Eluted proteins were run in Western blots with membranes probed against HIgM12. Molecular weights of eluted proteins from HIgM12-coated beads were in the range of $160-200 \mathrm{kDa}$ in addition to the IgMs heavy chain $(\sim 65-73 \mathrm{kDa})$. This figure has been modified from $\mathrm{J}$. Neurochem. ${ }^{15}$. Please click here to view a larger version of this figure. 
A. NCAM total KO: BRAIN
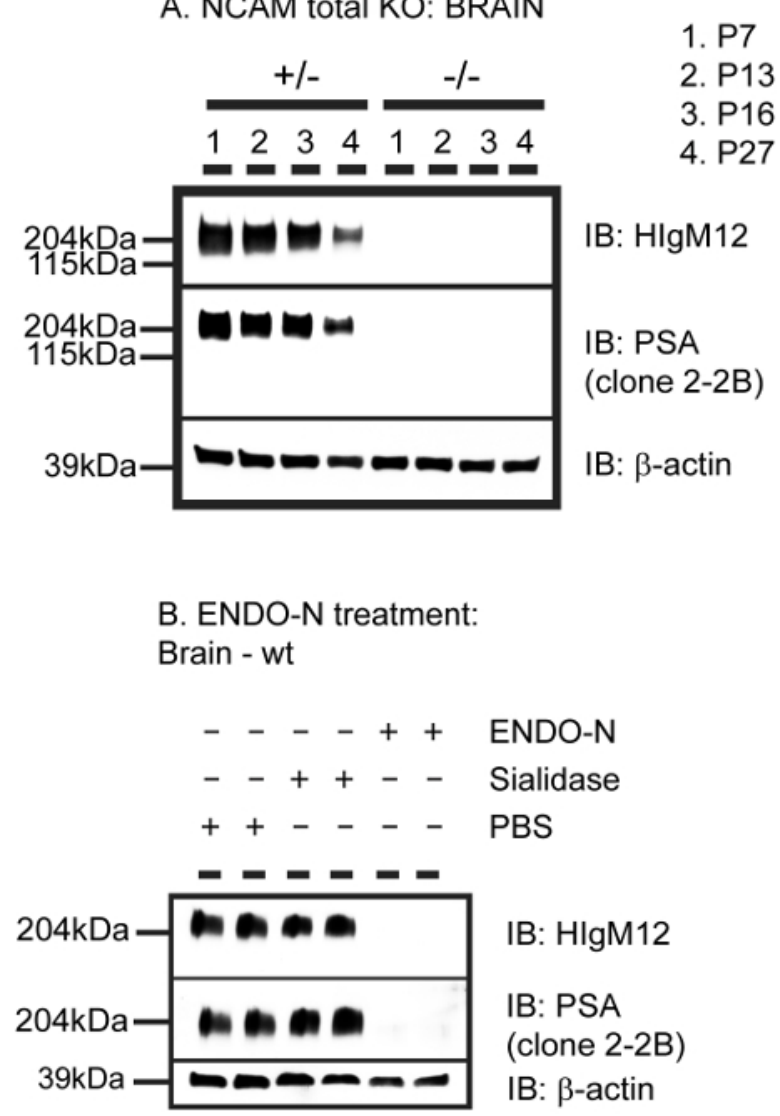

Figure 2: HIgM12 Targets the Polysialic Acid (PSA) Moiety on NCAM. A. Brain homogenates from P7, P13, P16 and P27 NCAM total $\mathrm{KO}$ mice and heterozygous littermate controls were run in Western blots with membranes probed against HIgM12, PSA and $\beta$-actin as loading control. B. $10 \mu \mathrm{g}$ of adult WT mouse brain lysate in $1 \%$ NP40 in PBS, pH 6.5 was treated with endoneuraminidase N (ENDO-N) (exo)neuraminidase with $\alpha 2-3$ polysialic acid polymer specificity (Sialidase) or PBS overnight at $37^{\circ} \mathrm{C}$, run as doublets in Western blots and probed against HIgM12, PSA and $\beta$-actin as loading control. This figure has been modified from $\mathrm{J}$. Neurochem. ${ }^{15}$. Please click here to view a larger version of this figure. 


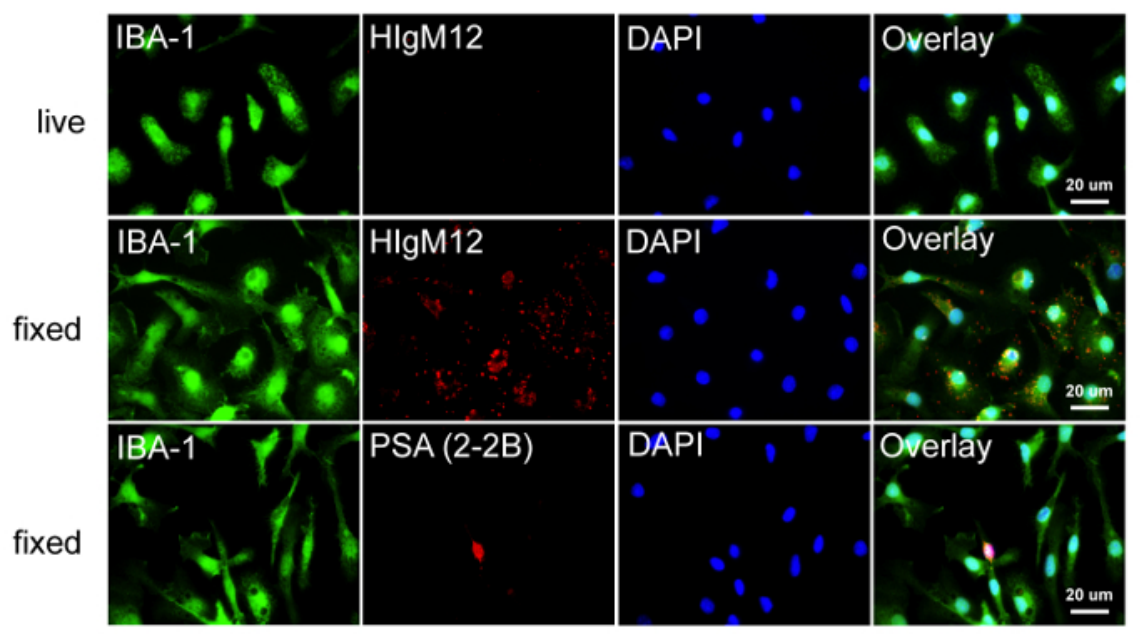

Figure 3: The Absence of PSA on Rat Microglia is Mirrored by a Lack of HIgM12 Labeling. Rat microglia were cultured for 48 hr on polyD-lysine coated glass coverslips and either labeled live on ice with HIgM12 or after fixation with HIgM12 or anti-PSA mAb (clone 2-2B). Cells were triple labeled with microglia marker IBA-1 (green), HIgM12/PSA (red) and DAPI (blue). Images show lack of microglial cell surface binding using HIgM12 (upper row) and lack of anti-PSA binding (clone 2-2B) to the cell surface and internal stores in primary rat microglia (lower row). Based on bipolar morphology and absence of IBA-1 staining, the small PSA-positive cell (lower row) was suggested to be an OPC. In fixed cells, HIgM12 staining resulted in a punctated, perinuclear pattern that was not restricted to specific organelles and was considered non-specific binding (middle row). Please click here to view a larger version of this figure.
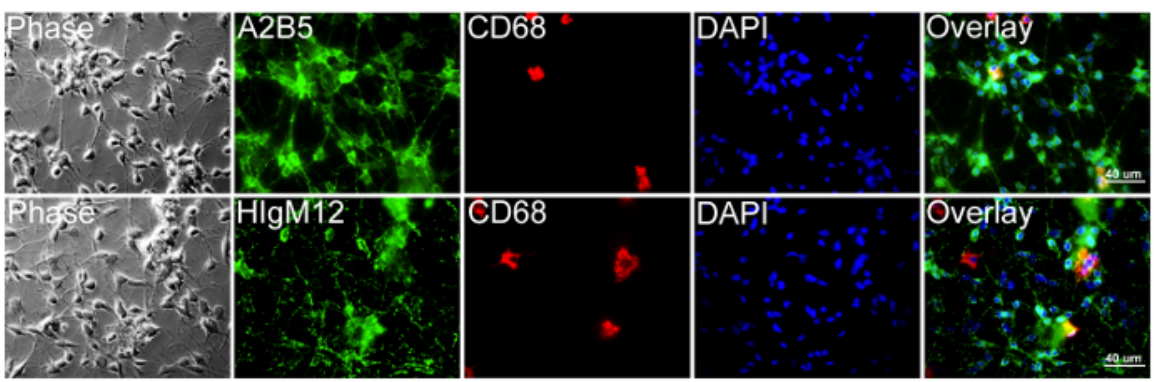

Figure 4: HIgM12 Targets Cell Surface PSA-NCAM on Rat OPCs. Rat OPCs and microglia were cultured for 4 days in proliferation medium on poly-D-lysine coated glass coverslips and triple labeled live on ice with HIgM12 or A2B5 (green), internal macrophage/monocyte marker CD68 (clone ED-1) (red) and DAPI (blue). Images show cell populations majorly positive for OPC marker A2B5 (upper row) and HIgM12 (lower row) with few CD68-positive microglia $(\sim 5 \%)$. Phase contrast and DAPI images were added to reveal cell integrity and cell numbers for each population. Please click here to view a larger version of this figure. 

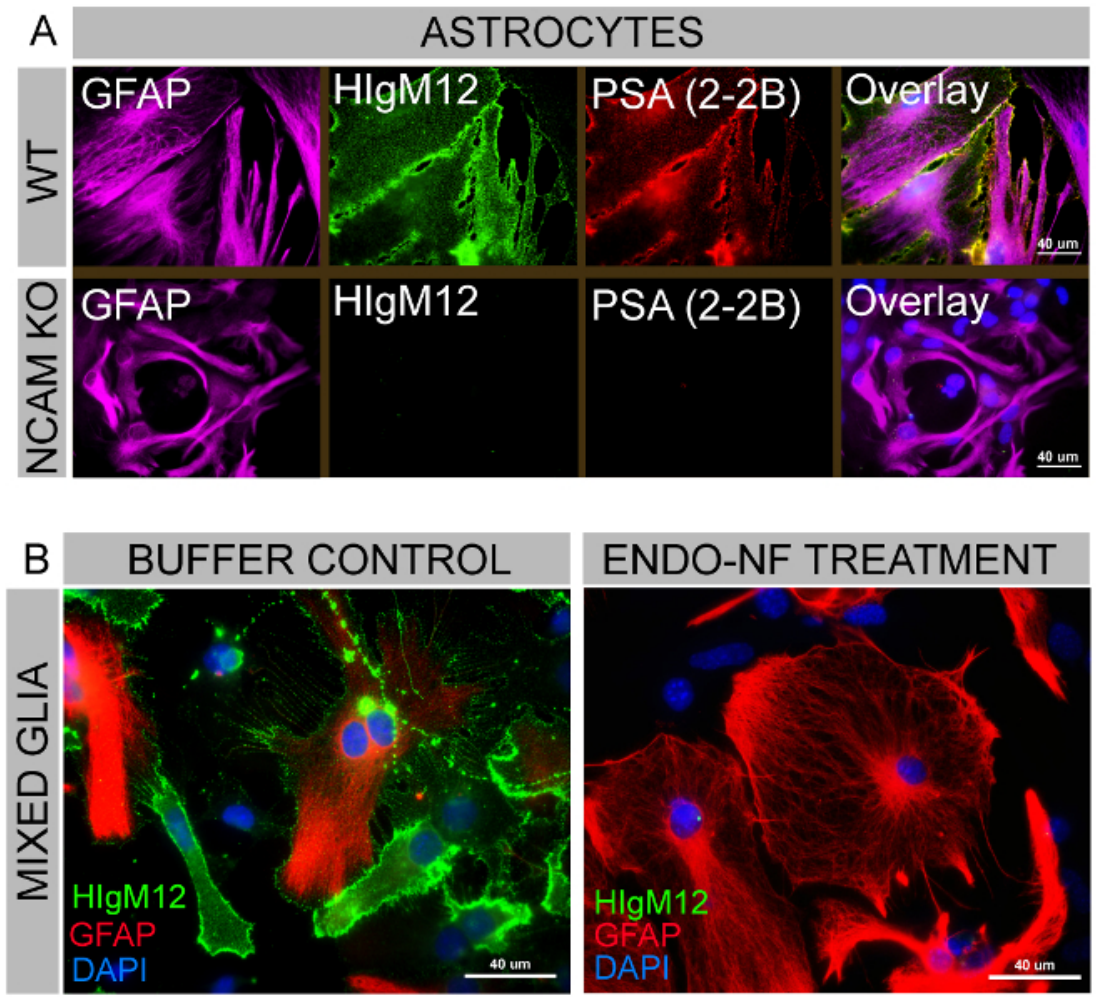

Figure 5: HIgM12 and anti-PSA mAb co-label an Astrocytic Subpopulation in Mouse Mixed Glia. A. Mouse mixed glial cells from WT and NCAM total KO animals containing astrocytes, oligodendrocyte-lineage cells and microglia were cultured for 3 days and labeled live on ice with HIgM12 (green), anti-PSA mAb (clone 2-2B) (red) and subsequently for astrocytic marker GFAP (purple) and DAPI (blue). HIgM12 and antiPSA reveal a virtual identical staining pattern on GFAP-positive WT astrocytes but lack binding to cultured astrocytes from NCAM KO mice. This figure has been modified from $\mathrm{J}$. Neurochem. ${ }^{15}$. B. Mixed glia were cultured identically as described under A. and treated overnight with endoneuraminidase-NF (kindly provided by Dr. Martina Muehlenhoff) or PBS control. Cells were labeled live on ice with HIgM12 (green) and subsequently stained for internal markers GFAP (red) and DAPI (blue). HlgM12 targets cell surface antigens on PBS-control treated mixed glial cultures but not endoneuraminidase-NF treated mixed glia. This figure has been modified from $\mathrm{JSCl}^{16}$. Please click here to view a larger version of this figure.

All images were taken at $60 \mathrm{X}$ magnification using the same instrument settings and processed identically. 


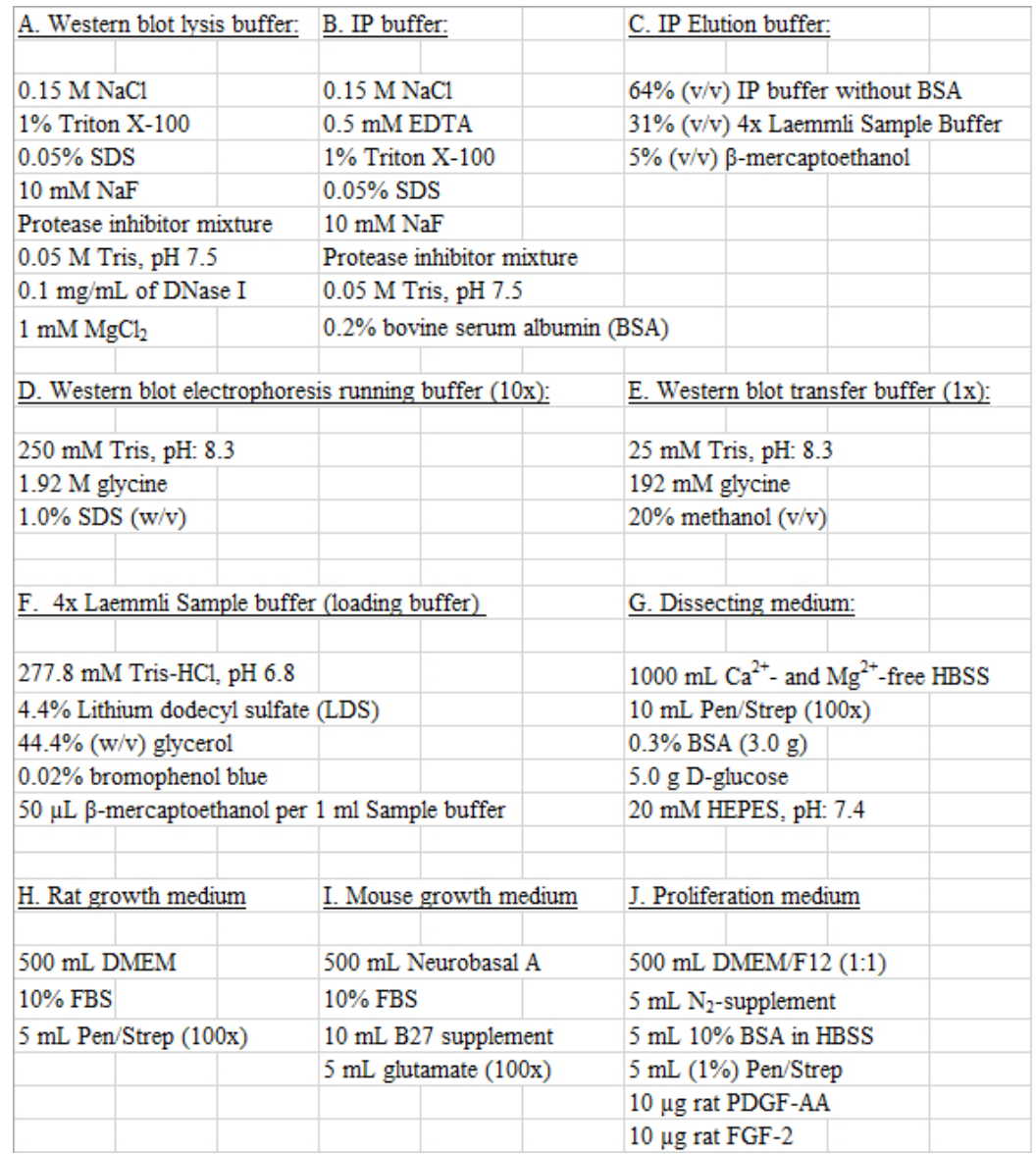

Table 1: Buffer and Solution Recipes. Please click here to download this table.

\begin{tabular}{|l|l|l|l|l|}
\hline & CNS tissue & ENDO-NF/PBS & Lysis buffer & Total volume \\
\hline 1. WT mouse & $67 \mu \mathrm{g}(0.45 \mu \mathrm{l})$ & $2 \mu \mathrm{l}(12 \mu \mathrm{g})$ ENDO-NF & $7.55 \mu \mathrm{l}$ & $10 \mu \mathrm{l}$ \\
\hline 2. WT mouse & $67 \mu \mathrm{g}(0.45 \mu \mathrm{l})$ & $2 \mu \mathrm{l}$ PBS & $7.55 \mu \mathrm{l}$ & $10 \mu \mathrm{l}$ \\
\hline 3. WT mouse & $67 \mu \mathrm{g}(0.45 \mu \mathrm{l})$ & no PBS or ENDO-NF & $9.55 \mu \mathrm{l}$ & $10 \mu \mathrm{l}$ \\
\hline 4. NCAM KO mouse & $67 \mu \mathrm{g}(0.45 \mu \mathrm{l})$ & $2 \mu \mathrm{l}(12 \mu \mathrm{g})$ ENDO-NF & $7.55 \mu \mathrm{l}$ & $10 \mu \mathrm{l}$ \\
\hline 5. NCAM KO mouse & $67 \mu \mathrm{g}(0.45 \mu \mathrm{l})$ & $2 \mu \mathrm{l}$ PBS & $7.55 \mu \mathrm{l}$ & $10 \mu \mathrm{l}$ \\
\hline 6. NCAM KO mouse & $67 \mu \mathrm{g}(0.45 \mu \mathrm{l})$ & no PBS or ENDO-NF & $9.55 \mu \mathrm{l}$ & $10 \mu \mathrm{l}$ \\
\hline
\end{tabular}

Table 2: ENDO-NF digestion of CNS tissue from P7 WT and NCAM KO mice.

\section{Discussion}

Human natural IgM autoantibodies are appealing candidates for immunotherapies and have demonstrated therapeutic potential for the treatment of various diseases including cancer and CNS disorders ${ }^{1-7}$. Advantageously, these antibodies will not elicit an immune response in which the generation of neutralizing antibodies substantially reduces the effective therapeutic dose and efficacy. Importantly, all antibodies with therapeutic potential have been of the IgM isotype and belong to the NAb repertoire ${ }^{3-5,8,9,37,40,42-45}$. A major hurdle for the potential clinical application of IgM antibodies is the identification of their antigens, which are undetermined in many cases. Standard techniques employed for lgG antibodies are often not applicable to identify an IgM's antigen.

This protocol describes the identification of PSA-NCAM as the antigen for the regenerative human IgM antibody HIgM12, effective in animal models of MS and ALS ${ }^{15-18}$. The methodology used is principally applicable to all human antibodies with specific $V_{K}$ light chains $V_{K}$, $V_{K} I I I$ and VKIV and mouse antibodies with VKI light chains, irrespective of the antibody's isotype.

The most critical step in this protocol is the use of IgM antibodies in affinity chromatography applications. More specifically, successful antibodies are required to act as pull-down agents in immunoprecipitations to isolate or to enrich an antigen out of complex tissue- or cell-culture lysates. Enriched antigen fractions may be compared to immunoprecipitations from isotype control antibodies and subsequently analyzed for differences by mass spectrometry. One essential requirement or limitation of this step is the presence of the correct antibody $V_{k}$ light chain and host (human, mouse) to enable antibody binding to protein $L$ agarose. Use of mannan-binding protein bound to agarose (also called mannose-binding lectin) instead of protein $L$ agarose is a potential alternative to immunoprecipitate lgMs without specific Vk light chains. However, as stated by 
Arnold et al. ${ }^{35}$, antigen-bound lgM antibodies do not bind to mannan-binding protein, as the target glycan appear to become inaccessible once the IgM has bound to its antigen. Based on these findings mannan-binding protein cannot be used as a binding matrix to immunoprecipitate antigen-loaded IgM molecules ${ }^{35}$. Other potential alternatives might be the use of secondary agarose-bound anti-lgM IgG antibodies ${ }^{46,47}$ or use of surface-activated magnetic beads ${ }^{48}$. IgG antibodies directed against IgMs could be chemically crosslinked to agarose $A$ or agarose $\mathrm{G}$ in order to reduce the extent of eluted antibody together with the antigen of interest. A proper comparison between different variants of lgM immunoprecipitation with respect to successfully identified antigens is difficult because most immunoprecipitations were performed to isolate or deplete IgMs without further interest in their antigens. In addition, immunoprecipitations using IgMs were mainly used to confirm an already known or expected single antigen with antibody exposure to purified antigens ${ }^{49}$. A disadvantage of agarose-coupled IgGs directed against human IgMs is a very low yield (10 - 15\%) of immunoprecipitated serum IgM molecules when compared to the starting material ${ }^{50}$. In contrast, surface-activated magnetic beads were successfully applied to antibodies of different isotypes including IgM to immunoprecipitate scrapieassociated fibrils ${ }^{48}$. This method is not restricted to specific kappa $\left(V_{K}\right)$ or lambda $(\lambda)$ chains or a particular host and may substantially broaden the spectrum of IgM antibodies used in immunoprecipitations.

Another important step in the protocol is the antibody's ability to function as a detecting antibody (primary antibody) in Western blots or other screening platforms. Successful antibodies must target their antigen with sufficiently high affinity to allow antigen binding in the presence of non-ionic or possibly ionic detergents. High affinity antibodies are common among affinity-maturated lgG antibodies, but less common among antibodies of the IgM isotype, which is one of the reasons why there are relatively few commercially available IgM antibodies as detecting agents in biochemical settings. High affinity binding of antibodies is a requirement for immunoprecipitations of molecular antigens and for Western blotting. Lowering detergent concentrations or the complete absence of detergents in IP buffers and lysis buffers allows antigen targeting by lowaffinity antibodies via its Fab domain. In contrast, the antibody's ability to target protein L agarose via its Fc portion is not substantially affected among isotype controls over a range of different detergent concentrations. However, low detergent concentration in lysis buffer and IP buffer prevents cell membrane disruption and isolation of specific molecules. Similarly, a low detergent concentration in Western blot washing buffers (e.g., PBS-T) allows antigen binding of low-affinity antibodies but at the same time increases non-specific binding and is therefore not an option.

The presence of an antigen protein core is another requirement for this method. Proteins with posttranslational modifications (e.g., glycoproteins, lipoproteins) and unmodified proteins, but not sole lipids or carbohydrates, are detectable in Western blots. It is not possible to immunoprecipitate lipids (e.g., sphingolipids) from tissue or cell lysates in the presence or absence of detergents. The physicochemical properties of detergents and lipids are too similar to allow selective lipid-antibody interactions, while at the same time detergents are essential to disrupt membranes in order to allow selective isolation of specific molecules. To our best knowledge, immunoprecipitations solely comprised of carbohydrate, in the absence of a protein core, have not been previously reported. This becomes particularly relevant because lgM antibodies frequently target carbohydrates and glycolipids, which are not necessarily linked to a protein unit. Other chromatographic techniques are required for the separation and immunologic identification of lipids and carbohydrates in the absence of a protein core. For example, thin layer chromatography (TLC) of cellular lipids with subsequent antibody detection on the TLC plate (immuno-TLC) can be implemented ${ }^{51,52}$

Other anti-PSA antibodies have been described in previous studies and results compared with HIgM12 as well as the commercially available anti-PSA IgM (clone 2-2B). The most commonly used antibody in the field of PSA is an IgG antibody (clone 735) available as mouse monoclonal or rabbit polyclonal antibody ${ }^{53}$. This anti-PSA IgG antibody detects PSA on SynCAM and NCAM on different CNS cell types including microglial cells $^{41}$. In contrast to the anti-PSA IgG antibody, human IgM antibodies HIgM12, HIgM42 and the anti-PSA mouse IgM (clone 2-2B) are unable to target PSA on SynCAM (but on NCAM) at various embryonic and early postnatal stages in mice, while non-polysialylated SynCAM is easily detectable ${ }^{15}$. The IgM antibodies used are also not able to detect PSA on microglial cells (Figures $3+4$ ). A possible explanation for differences observed between antibody isotypes may be low PSA-SynCAM levels compared to levels of PSA-NCAM combined with the potentially lower affinity binding of IgM antibodies compared to the anti-PSA IgG. To test this hypothesis, we performed immunoprecipitations in NCAM KO animals at embryonic stage E17 with vast amounts of SynCAM present and used HIgM12 as a "pull-down agent" ${ }^{15}$. In E17 WT littermate controls HIgM12 immunoprecipitated PSA-NCAM to an extent that showed similar intensities of "pulled down" PSA-NCAM compared to the IgMs heavy chain as detected by densitometry in subsequent Western blot using eluted antigens. This outcome suggested at least a sufficient affinity of HlgM12 to its target PSA. In contrast to WT littermate controls HIgM12 did not detect PSA attached to SynCAM in NCAM KO animals. Identical results were obtained in immunoprecipitations using the human anti-PSA IgM HIgM42. HIgM12 and HIgM42, as well as the mouse antiPSA IgM (clone 2-2B) were unable to target PSA on SynCAM in Western blots from WT and NCAM KO animals at embryonic and postnatal developmental stages. Given the low amount of HlgM12 required $(0.1 \mu \mathrm{g} / \mathrm{ml})$ to specifically detect PSA attached to NCAM in Western blots using small amounts of CNS tissue $(0.1 \mu \mathrm{g} \text { CNS tissue per well })^{15}$ it appears to be unlikely that low affinities alone are responsible for complete lack of PSA-SynCAM detection by HIgM12 in three different methods.

We conclude that there are significant differences between anti-PSA IgM antibodies and the frequently published anti-PSA IgG antibody (clone 735). It is not clear why commercially available anti-PSA IgM antibodies were not used more frequently in the past to confirm results obtained with antiPSA IgG antibody 735. This is particularly interesting because HIgM12 has already proven efficacy in different disease models. While other anti-PSA IgM antibodies may have similar therapeutic effects it remains unclear whether the anti-PSA IgG antibody (clone 735) has a similar therapeutic outcome in models of MS and ALS.

In brief, methods described here were used primarily to identify the antigen of the regenerative human antibody HIgM12 to support potential clinical trials for MS and possibly other neurodegenerative diseases. The identification of antigens for antibodies with biological activity is as essential step to understand their mechanism of action. This becomes particularly relevant in the context of numerous monoclonal antibodies currently being tested for safety and efficacy in human trials. While the number of clinically tested IgM antibodies to date is small, recent advances in hybridoma technology together with an increasing number of studies highlighting the therapeutic potential of this antibody class $1-10,37,40,42-45$ urges the development of new or modified methods applicable to identify non-protein IgM antigens.

\section{Disclosures}

Patents for antibodies that promote remyelination and CNS repair are issued and owned by Mayo Clinic. Authors have a potential conflict of interest. 


\section{Acknowledgements}

This work was supported by grants from the National Institutes of Health (R01 GM092993, R01 NS048357 and R21 NS073684), the National Science Foundation (CAREER Award), the Minnesota Partnership Award for Biotechnology and Medical Genomics, the National Multiple Sclerosis Society (CA1060A), and the Mayo Clinic Center for Clinical and Translational Science (CCaTS). The authors acknowledge support from the Applebaum, Hilton, Peterson and Sanford Foundations, the Moon and Marilyn Park Directorship Fund and the McNeilus family.

\section{References}

1. Asakura, K., Miller, D. J., Pease, L. R. Targeting of IgMkappa antibodies to oligodendrocytes promotes CNS remyelination. J Neurosci. 18 (19), 7700-7708 (1998).

2. Bieber, A. J., Warrington, A., Asakura, K. Human antibodies accelerate the rate of remyelination following lysolecithin-induced demyelination in mice. Glia. 37 (3), 241-249 (2002).

3. Vollmers, H. P., \& Brandlein, S. Natural antibodies and cancer. J Autoimmun. 29 (4), 295-302 (2007).

4. Vollmers, H. P., \& Brandlein, S. Natural antibodies and cancer. N Biotechnol. 25 (5), 294-298 (2009).

5. Vollmers, P. H., \& Brandlein, S. Natural monoclonal antibodies and cancer. Recent Pat Anticancer Drug Discov. 3 (2), $84-87$ (2008).

6. Warrington, A. E., Asakura, K., Bieber, A.J. Human monoclonal antibodies reactive to oligodendrocytes promote remyelination in a model of multiple sclerosis. Proc Natl Acad Sci. 97 (12), 6820-6825 (2000).

7. Warrington, A. E., Bieber, A.J., Ciric, B. A recombinant human IgM promotes myelin repair after a single, very low dose. J Neurosci Res. 85 (5), 967-976 (2007).

8. Brandlein, S., Pohle, T., Ruoff, N. Natural IgM antibodies and immunosurveillance mechanisms against epithelial cancer cells in humans Cancer Res. 63 (22), 7995-8005 (2003).

9. Pohle, T., Brandlein, S., Ruoff, N. Lipoptosis: tumor-specific cell death by antibody-induced intracellular lipid accumulation. Cancer Res. $\mathbf{6 4}$ (11), 3900-3906 (2004).

10. Miller, D. J., Sanborn, K. S., Katzmann, J. A. Monoclonal autoantibodies promote central nervous system repair in an animal model of multiple sclerosis. J Neuro. 14 (10), 6230-6238 (1994).

11. Acorda Therapeutics Inc. An Intravenous Infusion Study of rHlgM22 in Patients With Multiple Sclerosis (Clinical Trials Identifier NCT01803867). Available from: http://1.usa.gov/1N2gsHJ (2015).

12. Warrington, A. E., Bieber, A.J., Van Keulen, V. Neuron-binding human monoclonal antibodies support central nervous system neurite extension. J Neuropathol Exp Neurol. 63 (5), 461-473 (2004).

13. $\mathrm{Xu}, \mathrm{X}$., Warrington, A.E., Wright, B.R. A human IgM signals axon outgrowth: coupling lipid raft to microtubules. J Neurochem. 119 (1), 100-112 (2011).

14. Xu, X., Wittenberg, N.J., Jordan, L.R. A patterned recombinant human IgM guides neurite outgrowth of CNS neurons. Sci Rep. 32267 (2013).

15. Watzlawik, J. O., Kahoud, R.J., Ng, S. Polysialic acid as an antigen for monoclonal antibody HIgM12 to treat multiple sclerosis and other neurodegenerative disorders. J Neurochem. 134 (5), 865-878 (2015).

16. Watzlawik, J. O., Painter, M. M., Wootla, B. A human anti-polysialic acid antibody as a potential treatment to improve function in multiple sclerosis patients. J Nat Sci. 1 (8) (2015).

17. Xu, X., Denic, A., Jordan, L.R. A natural human IgM that binds to gangliosides is therapeutic in murine models of amyotrophic lateral sclerosis. Dis Model Mech. 8 (8), 831-842 (2015).

18. Denic, A., Macura, S.I., Warrington, A.E. A single dose of neuron-binding human monoclonal antibody improves spontaneous activity in a murine model of demyelination. PLoS One. 6 (10), e26001 (2011).

19. Lanier, L. L., Chang, C., Azuma, M. Molecular and functional analysis of human natural killer cell-associated neural cell adhesion molecule (N-CAM/CD56). J Immunol. 146 (12), 4421-4426 (1991).

20. Moore, S. E., Thompson, J., Kirkness, V. Skeletal muscle neural cell adhesion molecule (N-CAM): changes in protein and mRNA species during myogenesis of muscle cell lines. J Cell Biol. 105 (3), 1377-1386 (1987).

21. Pollerberg, E. G., Sadoul, R., Goridis, C. Selective expression of the $180-k D$ component of the neural cell adhesion molecule N-CAM during development. J Cell Biol. 101 (5 Pt 1), 1921-1929 (1985).

22. Seilheimer, B., Persohn, E., Schachner, M. Neural cell adhesion molecule expression is regulated by Schwann cell-neuron interactions in culture. J Cell Biol. 108 (5), 1909-1915 (1989).

23. Trotter, J., Bitter-Suermann, D., Schachner, M. Differentiation-regulated loss of the polysialylated embryonic form and expression of the different polypeptides of the neural cell adhesion molecule by cultured oligodendrocytes and myelin. J Neuro Res. 22 (4), $369-383$ (1989).

24. Yazaki, T., Asou, H., Arimoto, K. Decrease of NCAM expression and astrocyte-neurone interaction in long-term cultured astrocytes. Neuroreport. 6 (8), 1085-1088 (1995).

25. Zuber, C., Lackie, P. M., Catterall, W. A. Polysialic acid is associated with sodium channels and the neural cell adhesion molecule N-CAM in adult rat brain. J Biol Chem. 267 (14), 9965-9971 (1992).

26. Galuska, S. P., Rollenhagen, M., Kaup, M. Synaptic cell adhesion molecule SynCAM 1 is a target for polysialylation in postnatal mouse brain. Proc Natl Acad Sci. 107 (22), 10250-10255 (2010).

27. Curreli, S., Arany, Z., Gerardy-Schahn, R. Polysialylated neuropilin-2 is expressed on the surface of human dendritic cells and modulates dendritic cell-T lymphocyte interactions. J Biol Chem. 282 (42), 30346-30356 (2007).

28. Rollenhagen, M., Buettner, F.F., Reismann, M. Polysialic acid on neuropilin-2 is exclusively synthesized by the polysialyltransferase ST8SialV and attached to mucin-type o-glycans located between the b2 and c domain. J Biol Chem. 288 (32), 22880-22892 (2013).

29. Schnaar, R. L., Gerardy-Schahn, R., Hildebrandt, H. Sialic acids in the brain: gangliosides and polysialic acid in nervous system development, stability, disease, and regeneration. Physiol Rev. 94 (2), 461-518 (2014).

30. Abe, M., Goto, T., Kosaka, M. Differences in kappa to lambda (kappa:lambda) ratios of serum and urinary free light chains. Clin Exp Immunol. 111 (2), 457-462 (1998)

31. Bhattacharyya, D., Hammond, A. T., Glick, B. S. High-quality immunofluorescence of cultured cells. Methods Mol Biol. 619 403-410 (2010). 
32. Cremer, H., Lange, R., Christoph, A. Inactivation of the N-CAM gene in mice results in size reduction of the olfactory bulb and deficits in spatial learning. Nature. 367 (6462), 455-459 (1994).

33. Polo-Parada, L., Bose, C. M., Plattner, F. Distinct roles of different neural cell adhesion molecule (NCAM) isoforms in synaptic maturation revealed by analysis of NCAM $180 \mathrm{kDa}$ isoform-deficient mice. J Neurosci. 24 (8), 1852-1864 (2004).

34. Tomasiewicz, H., Ono, K., Yee, D. Genetic deletion of a neural cell adhesion molecule variant (N-CAM-180) produces distinct defects in the central nervous system. Neuron. 11 (6), 1163-1174 (1993).

35. Arnold, J. N., Wormald, M.R., Suter, D.M. Human serum IgM glycosylation: identification of glycoforms that can bind to mannan-binding lectin. J Biol Chem. 280 (32), 29080-29087 (2005).

36. Bjorck, L. Protein L. A novel bacterial cell wall protein with affinity for lg L chains. J Immunol. 140 (4), $1194-1197$ (1988).

37. Vollmers, H. P., Dammrich, J., Hensel, F. Differential expression of apoptosis receptors on diffuse and intestinal type stomach carcinoma. Cancer. 79 (3), 433-440 (1997).

38. Towbin, H., Staehelin, T., Gordon, J. Electrophoretic transfer of proteins from polyacrylamide gels to nitrocellulose sheets: procedure and some applications. Proc Natl Acad Sci. 76 (9), 4350-4354 (1979).

39. Stummeyer, K., Dickmanns, A., Muhlenhoff, M. Crystal structure of the polysialic acid-degrading endosialidase of bacteriophage K1F. Nat. Struct. Mol. Biol. 12 (1), 90-96 (2005).

40. Vollmers, H. P., Dammrich, J., Ribbert, H. Apoptosis of stomach carcinoma cells induced by a human monoclonal antibody. Cancer. 76 (4), 550-558 (1995).

41. Werneburg, S., Muhlenhoff, M., Stangel, M. Polysialic acid on SynCAM 1 in NG2 cells and on neuropilin-2 in microglia is confined to intracellular pools that are rapidly depleted upon stimulation. Glia. 63 (7), 1240-1255 (2015).

42. Brandlein, S., Rauschert, N., Rasche, L. The human IgM antibody SAM-6 induces tumor-specific apoptosis with oxidized low-density lipoprotein. Mol Cancer Ther. 6 (1), 326-333 (2007).

43. Vollmers, H. P., Hensel, F., Hermann, R. Tumor-specific apoptosis induced by the human monoclonal antibody SC-1: a new therapeutical approach for stomach cancer. Oncol Rep. 5 (1), 35-40 (1998).

44. Vollmers, H. P., O'Connor, R., Muller, J. SC-1, a functional human monoclonal antibody against autologous stomach carcinoma cells. Cancer Res. 49 (9), 2471-2476 (1989).

45. Vollmers, H. P., Zimmermann, U., Krenn, V. Adjuvant therapy for gastric adenocarcinoma with the apoptosis-inducing human monoclonal antibody SC-1: first clinical and histopathological results. Oncol Rep. 5 (3), 549-552 (1998).

46. Nakano, K., Yasuda, K., Shibuya, H. ANNALS EXPRESS: Transient human anti-mouse antibody generated with immune enhancement in a carbohydrate antigen 19-9 immunoassay after surgical resection of recurrent cancer. Ann Clin Biochem. (2016).

47. Pettingill, P., Kramer, H.B., Coebergh, J.A. Antibodies to GABAA receptor alpha1 and gamma2 subunits: clinical and serologic characterization. Neurology. 84 (12), 1233-1241 (2015).

48. Morel, N., Simon, S., Frobert, Y. Selective and efficient immunoprecipitation of the disease-associated form of the prion protein can be mediated by nonspecific interactions between monoclonal antibodies and scrapie-associated fibrils. J Biol Chem. 279 (29), $30143-30149$ (2004).

49. Lobo, P. I., Schlegal, K. H., Vengal, J. Naturally occurring IgM anti-leukocyte autoantibodies inhibit T-cell activation and chemotaxis. J Clin Immunol. 30 Suppl 1 S31-36 (2010).

50. Lobo, P. I., Schlegel, K.H., Spencer, C.E. Naturally occurring IgM anti-leukocyte autoantibodies (IgM-ALA) inhibit T cell activation and chemotaxis. J Immunol. 180 (3), 1780-1791 (2008).

51. Wikstrand, C. J., Fredman, P., Svennerholm, L. Detection of glioma-associated gangliosides GM2, GD2, GD3, 3'-isoLM1 3',6'-isoLD1 in central nervous system tumors in vitro and in vivo using epitope-defined monoclonal antibodies. Prog Brain Res. 101 213-223 (1994).

52. Hamilton, W. B., Helling, F., Lloyd, K. O. Ganglioside expression on human malignant melanoma assessed by quantitative immune thin-layer chromatography. Int J Cancer. 53 (4), 566-573 (1993).

53. Galuska, S. P., Oltmann-Norden, I., Geyer, H. Polysialic acid profiles of mice expressing variant allelic combinations of the polysialyltransferases ST8Siall and ST8SialV. J Biol Chem. 281 (42), 31605-31615 (2006). 